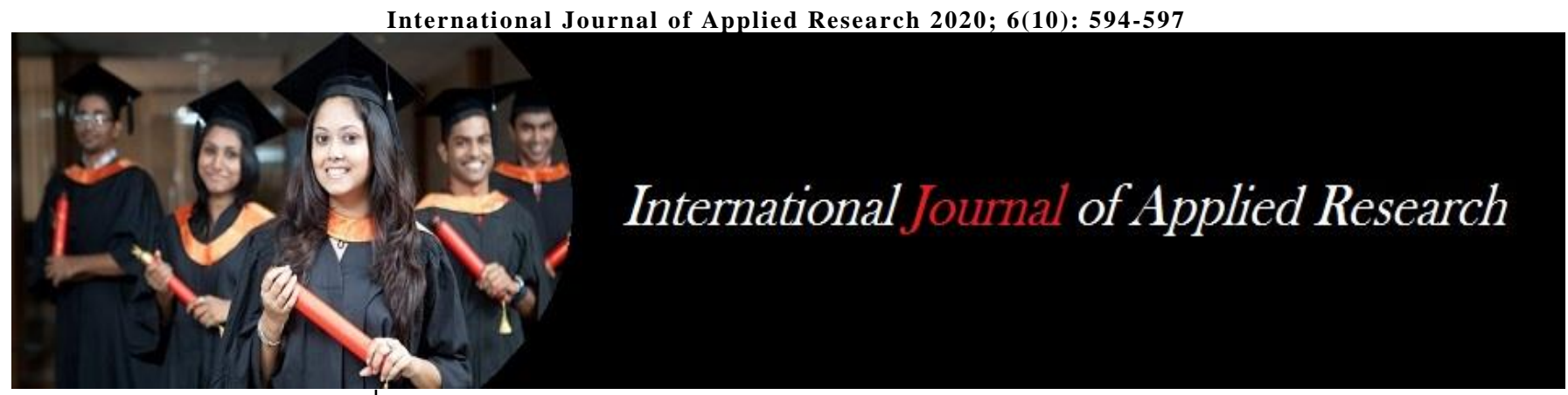

ISSN Print: 2394-7500 ISSN Online: 2394-5869 Impact Factor: 5.2 IJAR 2020; 6(10): 594-597 www.allresearchjournal.com Received: 12-08-2020 Accepted: 16-09-2020

Swati Kumari

CDA Colony, House No.-22

North, Shastrinagar

PO+Post- Shastrinagar

Patna, Bihar, India
Corresponding Author: Swati Kumari

CDA Colony, House No.-22

North, Shastrinagar

PO+Post- Shastrinagar

Patna, Bihar, India

\section{Impact of migrartion in multi-dimensional aspects of Mithila region}

\section{Swati Kumari}

DOI: https://doi.org/10.22271/allresearch.2020.v6.i10j.7417

\section{Abstract}

It was observed that the efficiencies of human labour and irrigation in rice production were higher than non-migrant households and statistically significant, indicating rational use of these two critical inputs on migrant households in Mithila. The consequences of migration corroborates that neither the migrants themselves nor the areas of in-migration and out-migration remain the same, once a migration-current develops. The areas of cities are growing and the areas of villages are decreasing. The same trend we can see in metropolises as their area and population increasing day-by-day due to consequence of migration. All these measures will help arrest the migration inflow to metropolitan cities and bring about balanced urban development.

Keywords: Manpower, migration, migrate, labour, population

\section{Introduction}

Migration of population has been a recurrent phenomenon sincedown of human history. Though its form has changed but remains since as very dominant phenomenon in the global social system. In modem days also people migrate from underdeveloped areas to the developed ones in search of better employment and opportunity. They are for reaching consequences of migration of male labour force on their place of origin. Keeping in view the anticipated consequences of migration in place of origin, this study has been undertaken to examine the impact of male labour out-migration on rice productivity, livelihood and women empowerment on migrant household in Mithila. It was observed that the efficiencies of human labour and irrigation in rice production were higher than non-migrant households and statistically significant, indicating rational use of these two critical inputs on migrant households in Mithila.' This observation leads to the conclusion that the migration might have helped in judicious use of human labour at native place due to migration of surplus labour force for gainful employment to destination of migration. Remittances have been utilize for meeting consumption needs, improved livelihoods better education to children and better health care facilities which help in overall improvement in livelihood on migrant households in Mithila. Migrant households also preferred to save money to meet their requirements in unforeseen situations. Hence, migration can be said to be one of risk-coping strategies for the weaker sections of the society and helped developing the saving habits among migrant households.

The allocation of remittances on agricultural inputs could have increased if proper infrastructure facilities were present in rural areas for faster dissemination of modern agricultural technology for increasing agricultural production. Level of women employment has increased on poor households, however, work load of women has also increased. It has been observed that role of women of migrant households changed from unpaid female labour to mangers of the households, however, they we problem in management of fund, technology and input-output marketing. There is a need to launch a programme for their training to improved their knowledge in financial, technological and marketing management ${ }^{[2]}$.

It has widely been recognised that migration offers the area of out-migration, the area of inmigration and the migrants themselves. Grainier rightly remarks that each migrant, by the nature, seeks to recreate something of the original milieus in the midst of the new 
environment and consequently, enriches the civilization. This, the consequences of migration are no less significant than the causes of migration. Consequence of migration, which so far has received little attention, thus, offers another area for vital research for the population geographers of the coming generations.

The area from which the people move out and the area to which the people move in both undergo a quantitative as well as qualitative change in their demographic structure ${ }^{[3]}$. Since population movements are the expression of reallocation of human resources with a view to achieving better balance between human resources and physical resources therefore, the population-resource relationship of the two areas involved in the process of migration gets modified significantly as a result of the movement. With the movement of the people from on e area to another all the demographic attributes like, numbers, density, growth, fertility, Mortality, age, sex, literacy, etc. Experience a quantitative change in their numerical expressions. But the study relating to the consequences of migration should not be limited to the description of these numerical expressions and should try to look beyond these simple quantitative expressions. For instance, an increase in the density of' opulation. Through migration, may either increase the region's burden $\mathrm{P}$ resources or may enhance the capacity to exploit its resource potential. white analysing the consequences of population movement, Population geographers should examine this aspect mart carefully. Similarly, similarly, the movement of educated and technically trained people into to area may not only be seen in terms of the proportional increase in literacy but also it should be examined in terms to the change such an inmigration may result in the quality of life in the region ${ }^{[4]}$.

The migrants, on the other hands also face serious adaptation problems, e.g., the rural migrants moving to the new industrial towns sager from lack of pure air and open space, noxious fume, dust, etc. They also have to adapt to the new dietary habits and timings of food. There are evidences to prove that the incidence of respiratory diseases among the people who migrate from rural areas to industrial towns in very high. Sometimes, the physical contact of the people belonging to two different pathological backgrounds may change the pathogenic complex of the two types of people involved. Greater interaction between people of Mithila region and of other region of the country, consequently, the diseases which were formerly inoffensive have now become deadly. The consequences of migration corroborates that neither the migrants themselves nor the areas of in-migration and out-migration remain the same, once a migration-current develops ${ }^{[5]}$. Also with each wave of migrants there is not only a quantitative change in the demographic character of the two areas but also there is a qualitative change in the Personality of the two areas. Above all, the civilization gets enriched due to the contributions of the migrants who integrate the two areasanhde therein lies the greatest benefit of migration. In assessing determinants and consequences migration. Those who advocate or at least try to defend the free flow of human capital often fail to distinguish between professional manpower and less high trained or skilled labourers. The determinants and perhaps even mare the consequences of the oigration of the latter may be entirely different from those pertaining to professional manpower, if for no other reason than that they represent a smaller investment and are generally in more amply supply. What is more, such advocates often fail to distinguish between the different categories of professional manpower - those of physicians and nurses may be entirely different from those, for example, of nuclear scientists and engineers. The mere fact that physicians and nurses essentially provide service directly to people and that population size has always been a factor in a calculating needs, particularly for physicians, places such manpower in a category that is very different from that of manpower concerned with either the development of products, the development of production processes, or the production of goods. In more concrete terms, the argument would be that, when even one physician emigrates, hundreds of people in his homeland may actually or potentially be denied health services ${ }^{[6]}$.

(On the contrary, in more prolific Mithila region in which the general increase has been more considerable, as in the Darbhanga, the phenomenal growth of the district. Differences are equally distinguishable within a state and a country, between town and metro cities. But the anomalies are not the same, varying with the stage of technical and economic evolution. In the least developed area or Mithila region, it is the men who go off, more or less for good, leaving their women in the village. The crops are therefore It tended, whilst in the towns, the scarcity of the female element put a price on it and leads to bad habits. Divorces multiply, prostitution is rampant and becomes a profitable trade ${ }^{[7]}$.

\section{Contribution of migration to urbanization}

Migration is one of the important factors contributing to the growth of urban population. The total urban population of the country. The migration data of 2001 Census indicates that 20.5 million people enumerated in urban areas are migrants from rural areas who moved in within the last 10 years. There are 6.2 million migrants who have similarly migrated from urban areas to rural areas. Thus the net addition to urban population on account of migration is 14.3 million. This works out to be 6.6 per cent of the urban population in 1991. In other words, out of the urban growth of 30.3 per cent, 6.6 per cent is accounted for by migration to urban areas. Thus, natural growth of urban population and growth due to formation of new urban settlements and extension of areas of towns during 1991-2001 adds up to 23.7 percent.

\section{Migration into Urban Agglomerations}

2001 Census data also presents migration data by last residence for each Urban Agglomeration (or UA) and City in the country, allowing specific examination. The inflow of migrants depends upon the size of the IJAkity as in large UAs and Cities the availability of work/employment is greater. However, in terms of amenities and services, inmigration causes a severe pressure, as these are not commensurate to high growth in population. Below provides a comparison of migrants by last residence during last ten years into important UAs and their share to total UA population, thus providing an insight in to the fast pace in which the migration is taking place in these centres ${ }^{[8]}$.

\section{Migration from neighbouring countries}

To examine, further, the data on migration based on last residence from neighbouring countries, who in fact constitutes the bulk of the international migration in India. 
On migration by last residence shows that there were 4.9 million persons who migrated from the neighbouring countries, constituting about $96.9 \%$ of the total migrants from abroad. The bulk of these migrants were from Bangladesh who were about 3.0 million in number, the next important group being those from Pakistan ( 0.9 million) and Nepal ( 0.5 million). If one examines the trends of migration from neighbouring countries over the years a slowing down in migration is evident. Bulk of the international migration shown above relates to '20 years or above' category, pointing towards migration at the time of partition or the formation of Bangladesh in 1971. Large scale migration from across the border seems to have declined after that, except in case of Bangladesh. The rising number of migrants from Nepal over the years is also important ${ }^{[9]}$.

\section{Quantum of remittances}

No formal data on the total value of remittances exist but some idea can be gained from Post Office data on Money orders. Although not all MOs are sent by migrants they do account for much of the money sent in this way to rural Mithila. According to Post Office officials the total value of MOs sent to Bihar from other parts of India was Rs 450 crores in 2005- 2006. However this represents a fraction of the total money sent and carried to Mithilanchal by migrants. The rate of increase of MOs has slowed down recently as other remittance mechanisms become popular: it fell from $13 \%$ in 2004 to just under $4 \%$ in 2005 . But there are seasonal fluctuations which reflect the seasonality of migration as the flows to North Bihar show below (South Bihar not provided).

\section{Debt and borrowing and its links with migration}

It has been argued that migration worsens poverty because migrant households are often in debt. But the relationship between debt and migration is not straightforward. While some analysts have concluded that migration increases debt levels because of higher expenditures during transit and at the destination, others have argued that migration improves the creditworthiness of households and they are able to borrow more because of that (Ghate 2005). Borrowing before migration and repaying after returning continues and is especially widespread among poorer migrants. However it was mentioned in several places that borrowing food grains from the rich to tide over the lean season and borrowing at very high interest rates for survival had virtually disappeared because of migration.

\section{The negative impacts of migration}

There are heavy costs associated with migration too - long separation from one's family brings isolation and loneliness; many are engaged in dirty dangerous and degrading occupations that affect their health and others engage in high risk sexual behaviour and fall prey to STDs or HIV/AIDS. Women and children who are left behind also suffer from loneliness, anxiety and vulnerability to sexual exploitation. Children who migrate with their parents miss school. As staff from Adhithi in Muzzaffarpur note "Remittances have made families able to live a better and relatively financially secure life, free of heavy, cumulative indebtedness, but at the same time women headed households and children suffer socially. They are on the track of a slow death.
Migrants from Mithilanchal who have gone for longer periods come to their native place twice or thrice in a year for important festivals like Durga puja, Chchat puja. This serves the purpose of meeting relatives and renewing friendships.

Data suggest that migration has some impact on the village of origin, through it is not very significant. Monetary transfer from destination to origin is almost non-existent and there is hardly any investment ploughed back into the lands of the migrants. Most of the earnings are used for necessities like food and clothing. There is however, a sustained contact maintained with relatives and it is somewhat stronger in the case of migrants with lands who lease them out ${ }^{[10]}$.

Thus, the Mathilanchanl emigrants, while abroad, can have an effect on the economy and social ranking of those in their home area. The conflict Phase is a time of social tension and rapid change. Often, Wives children and other family members come and assert adherence to norms of the home society ${ }^{[11]}$. In the meantime, they have to also live Within the dictates of the receiving culture, which imposes on the migrants confliction sets of rules to follow. The trauma becomes more acute as the second generation comes into prominence. During this time, the home village continues to be influenced by her emigrants, and it is likely that emigration continues to be popularized to make it a goal for many to achieve ${ }^{[\mathbf{1 2}]}$. The receiving society, however, can no longer ignore the new people settling in their midst and have to deal with the new population which is a matter of concern [13].

In fact, More migrants are to be found in five important industrial catogeries of manufacturing, other servies, trade and commerce, transport and construction. The social and economic consequences of urbanization in terms of unemployment and underemployment and the growth of slum population in cities [14]. The consequence of uncontrolled Immigration in the towns of Mithila region namely Darbhanga, Purnea, Muzaffarpur, Katihar, Madhubani have started dying gradually, unable to cope with the enormous problems they are facing like air, water and sound pollution, inadequacy of water and electric supply, disposal of rubbish and sewage, transport, educational, medical and recreational facilities, mushroom growth of slums due to inadequate housing and lack of sites for constructing house, high rate of unemployment and underemployment, rise in the population of the urban poor people.

The consequence of migration, other cities and small towns have started decaying. One major consequence of migration is the area of cities are growing became ambience to village areas, more specifically. The areas of cities are growing and the areas of villages are decreasing. The same trend we can see in metropolises as their area and population increasing day-by-day due to consequence of migration. There is an immediate need to curb the growth of the metropolises and other bigger cities by not issuing licenses for starting new industries, decentralising the existing industries, starting industries in the industrially backward districts, encouraging the establishment of cottage and small-scale industries in the villages and small towns, improving agriculture, horticulture, dairying and animal husbandry, bringing more land under irrigation, implementing land reforms providing drinking water, schools and higher educational institutions, primary health units and primary health centres and 
hospitals, constructing homes for the lower middle and lower classes, removing untouchability and bringing about communal harmony in the villages. All these measures will help arrest the migration inflow to metropolitan cities and bring about balanced urban development.

\section{References}

1. Jha JC. migration and Achievements of Mithila Panditas Janki publications Patna, Delhi, 1991.

2. Valunjkar TN. Social organization, Migration and change in a village community, Deccan college, Poona, 1960.

3. Chandan RC, Sidhu MS. Introduction to population Geography, kalyani publishers, New Delhi, 1980,

4. Beaujeu, Gamier J. Geography of population, Logman, London, 1966.

5. Kshirasagar S. patterns of Internal Migration of males in India; Inter-state and Inter-state Flows", Artha vijana, 1973; 15(2):161-179,

6. Parish Jr. Wiliam L. Internal Migration and Modernization The European case, Economic Development and cultural change. 1973; 21(4):519-609.

7. John Prahhau SJ. Social and Cultural diterminalts of fertility in India India, International publication, Allahabad, priya Deshingkar, Sushil Kumar, 1974.

8. The Role of Migration and Remittances in promoting Livelihoods in Bihar, overseas Development Institute, London, De, 2006.

9. Clark, colin and Margaret Haswell. The Economies of Subsistence Agriculture, Mac millan, London, 1969.

10. Gmelch, George, "Return Migration",. In Annual Review of Anthropology, Palo Alto, California, Annual Reviews Ins., 1980, 9.

11. Tinker, Hugh, A New System of Slavery: The export of Indian Labour Overseas 1830-1920, Oxford University Press, Bombay, 1974.

12. Swanson, jon, "The Consequences of Emigration for Economic Development: A Review of the Literature", in Papers in Antropology 1979; XX:1

13. Manzoor Alam S. A study in Urban Geography, Asia publishing House, pp.212 Bombay, 1972

14. Sinclair W. Urbanization and Labour markets in developing countries, Manohar publication, New Delhi, 1978, 124. 